Supplement of Biogeosciences, 16, 2189-2204, 2019

https://doi.org/10.5194/bg-16-2189-2019-supplement

(C) Author(s) 2019. This work is distributed under

the Creative Commons Attribution 4.0 License.

(c) (1)

Supplement of

\title{
Microbial biobanking - cyanobacteria-rich topsoil facilitates mine rehabilitation
}

Wendy Williams et al.

Correspondence to: Wendy Williams (wendy.williams@uq.edu.au)

The copyright of individual parts of the supplement might differ from the CC BY 4.0 License. 


\section{Supplementary Tables}

Table S1: Descriptions of sources for intact biocrusts used to characterise the cyanobacterial communities: Site vegetation associations: SMU 1 - Red Mallee: Eucalyptus oleosa ssp. oleosa = open Mallee/Myall woodland; SMU 2 - Chenopod Shrubland: Maireana sedifolia and Atriplex vesicaria; SMU 3 - Western Myall: Acacia papyrocarpa Maireana sedifolia = open Myall woodland Site 1 occurs in a transition between SMU 2 and SMU 3 but was treated as most like SMU 2; Site 6 originated from SMU 3 - *2YO stockpile crust type determined in situ also with mosses present; TSF = Tailings storage facility.

\begin{tabular}{clcll} 
Site no. & Primary Vegetation & SMU & Biocrust types & Site identifier and description \\
\hline 1 & Western Myall & 2 & Types 2-5 & Edge year 3 clearance \\
2 & Western Myall & 3 & Types 2-5 & Dust mon track \\
3 & Western Myall & 3 & Types 2-5 & Drill track \\
4 & Red Mallee & 1 & Types 1-3 & Drill track - dune \\
5 & Red Mallee & 2 & Types 2-5 & Drill track - gilgai \\
6 & Western Myall & NA & Type 1* & Topsoil stockpile \\
7 & Western Myall & 3 & Types 2-5 & West side TSF \\
8 & Chenopod & 2 & Types 2-5 & Power Station site \\
9 & Red Mallee & 1 & Types 1-2 & Canberra - dune \\
10 & Red Mallee & 1 & Types 1-3 & Nth of pit - slight dune \\
\hline
\end{tabular}


Table S2: Descriptions of biocrust morphotypes (see Büdel et al., 2009; Doudle et al., 2011)

No. Crust Type Identification

1 Light (pale coloured) thin cyanobacterial crust in early stages of development: early-successional

2 Cyanobacterial crust, well established, intermediate stages of development
Patchy, brittle, bare patches visible, slight discolouration
3 Biocrust, well established, with cyanolichens: latesuccessional
Larger pieces can be easily removed intact, darkt discolouration
4 Biocrust, well established, with cyanolichens and/or green algal lichens: late-successional
Larger pieces can be easily removed intact, cyanolichens easily seen with hand lens (10x)
5 Biocrust (see Type 4) with mosses: latesuccessional
Larger pieces can be easily removed intact, liche easily seen with hand lens $(10 x)$ 
Table S3: Topsoil stockpile ages, locations and sampling depths

\begin{tabular}{|c|c|c|c|c|c|c|c|c|c|}
\hline $\begin{array}{l}\text { Stockpile } \\
\text { number }\end{array}$ & $\begin{array}{l}\text { Date of topsoil } \\
\text { stockpiling }\end{array}$ & $\begin{array}{l}\text { Stockpile } \\
\text { Replicate }\end{array}$ & Latitude & Longitude & $\begin{array}{l}\text { Adjacent } \\
\text { replicate }\end{array}$ & Latitude & Longitude & Soil sample depths $(\mathrm{cm})$ & $\begin{array}{l}\text { Date } \\
\text { sampled }\end{array}$ \\
\hline 10 & $31 / 10 / 2009$ & 1 & 0234527 & 6578956 & 1 & 0234433 & 6578944 & $0-2,2-4,4-6,10,25,50,50$ (sterilised control) & $8 / 3 / 12$ \\
\hline 10 & $31 / 10 / 2009$ & 2 & 0234542 & 6578921 & 2 & 0234422 & 6578933 & $0-2,2-4,4-6,10,25,50,50$ (sterilised control) & $8 / 3 / 12$ \\
\hline 10 & $31 / 10 / 2009$ & 3 & 0234557 & 6578881 & 3 & 0234436 & 6578913 & $0-2,2-4,4-6,10,25,50,50$ (sterilised control) & $8 / 3 / 12$ \\
\hline 12 & $6 / 11 / 2009$ & 1 & 0233396 & 2578200 & 1 & 0233414 & 6578180 & $0-2,2-4,4-6,10,25,50,50$ (sterilised control) & $8 / 3 / 12$ \\
\hline 12 & $6 / 11 / 2009$ & 2 & 0233377 & 6578206 & 2 & 0233437 & 6578227 & $0-2,2-4,4-6,10,25,50,50$ (sterilised control) & $8 / 3 / 12$ \\
\hline 12 & $6 / 11 / 2009$ & 3 & 0233362 & 6578218 & 3 & 0233431 & 6578263 & $0-2,2-4,4-6,10,25,50,50$ (sterilised control) & $8 / 3 / 12$ \\
\hline 18 & $13 / 07 / 2010$ & 1 & 0234870 & 6578033 & 1 & 0234878 & 6577787 & $0-2,2-4,4-6,10,25,50,50$ (sterilised control) & $9 / 3 / 12$ \\
\hline 18 & $13 / 07 / 2010$ & 2 & 0234852 & 6578023 & 2 & 0234873 & 6577776 & $0-2,2-4,4-6,10,25,50,50$ (sterilised control) & $9 / 3 / 12$ \\
\hline 18 & $13 / 07 / 2010$ & 3 & 0234860 & 6578007 & 3 & 0234853 & 6577782 & $0-2,2-4,4-6,10,25,50,50$ (sterilised control) & $9 / 3 / 12$ \\
\hline 19 & $29 / 06 / 2010$ & 1 & 0234999 & 6578800 & 1 & 0234922 & 6578851 & $0-2,2-4,4-6,10,25,50,50$ (sterilised control) & $9 / 3 / 12$ \\
\hline 19 & $29 / 06 / 2010$ & 2 & 0235000 & 6578820 & 2 & 0234918 & 6578856 & $0-2,2-4,4-6,10,25,50,50$ (sterilised control) & $9 / 3 / 12$ \\
\hline 19 & $29 / 06 / 2010$ & 3 & 0235003 & 6578834 & 3 & 0234913 & 6578849 & $0-2,2-4,4-6,10,25,50,50$ (sterilised control) & $9 / 3 / 12$ \\
\hline 20 & 2011 & 1 & 023457 & 6577150 & 1 & 0234938 & 6577286 & $0-2,2-4,4-6,10,25,50,50$ (sterilised control) & $8 / 3 / 12$ \\
\hline
\end{tabular}

\section{Supplementary Figures}




\section{Location: 016098 TARCOOLA AERO}

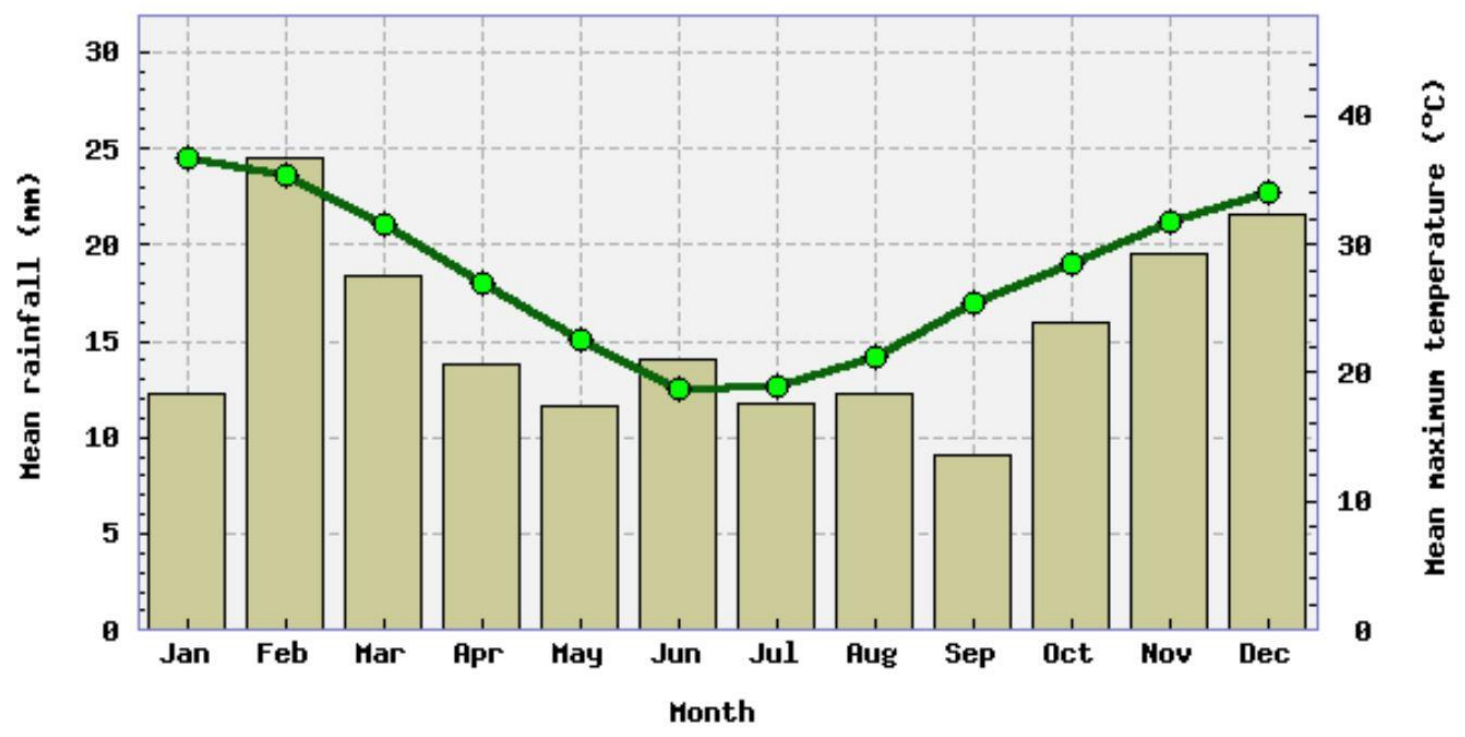

$\square 016098$ Mean rainfall (mm)

016098 Mean maximum temperature $\left({ }^{\circ} \mathrm{C}\right)$

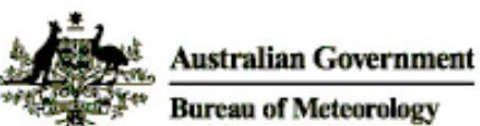

Figure S1: Mean monthly maximum temperature and rainfall data from nearby Tarcoola aerodrome for the past 20 years (source: bom.gov.au) 

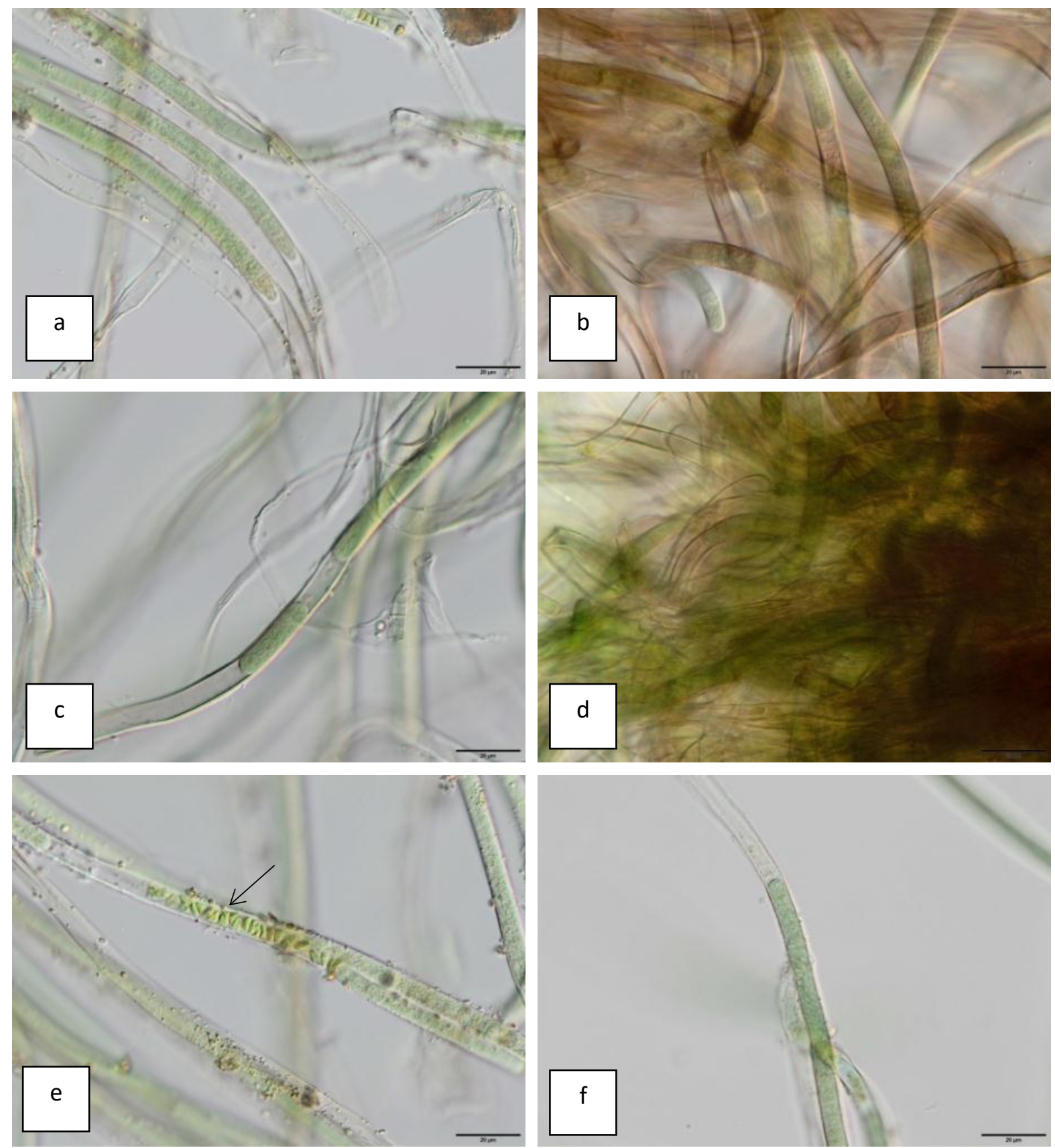

Figure S2: (a-f) The predominant Symploca species found across all sites; (b) illustrates distinctive colour found in those with UV pigmentation; (c) thin outer sheath; (d) masses of filaments that form mats; (e) desiccated cells inside sheath following period of time without moisture (arrow) and other cells already rehydrated; (f) filament with typical elongated sock-like sheath; (Scale bars $20 \mu \mathrm{m})$. 

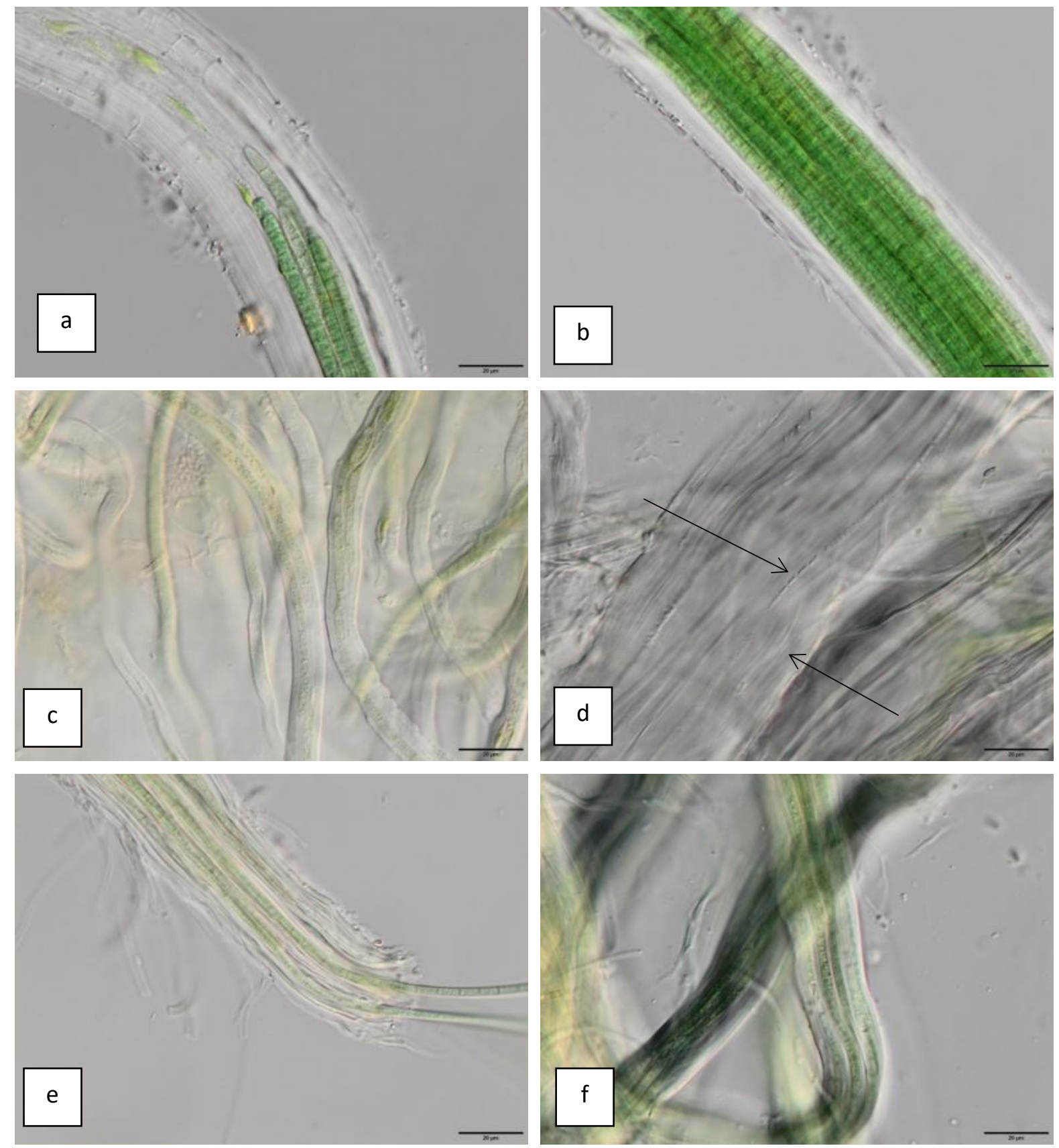

Figure S3: (a-b) Microcoleus paludosus with multiple bright trichomes encased in a common clear gelatinous sheath; (c-f) Schizothrix; three species were observed with varying morphological structure that included long entangled filaments with enclosed ends; Schizothrix was a subsurface species but was often found on the surface during a growth phase; (d) Schizothrix had thick, sticky, gelatinous sheaths (arrow), often with fine, almost invisible trichomes (arrow), and was hard to separate from the soil particles; (e-f) typically one or two trichomes encased in gelatinous sheaths clumped together to form rope-like filaments; (scale bars $20 \mu \mathrm{m}$ ). 

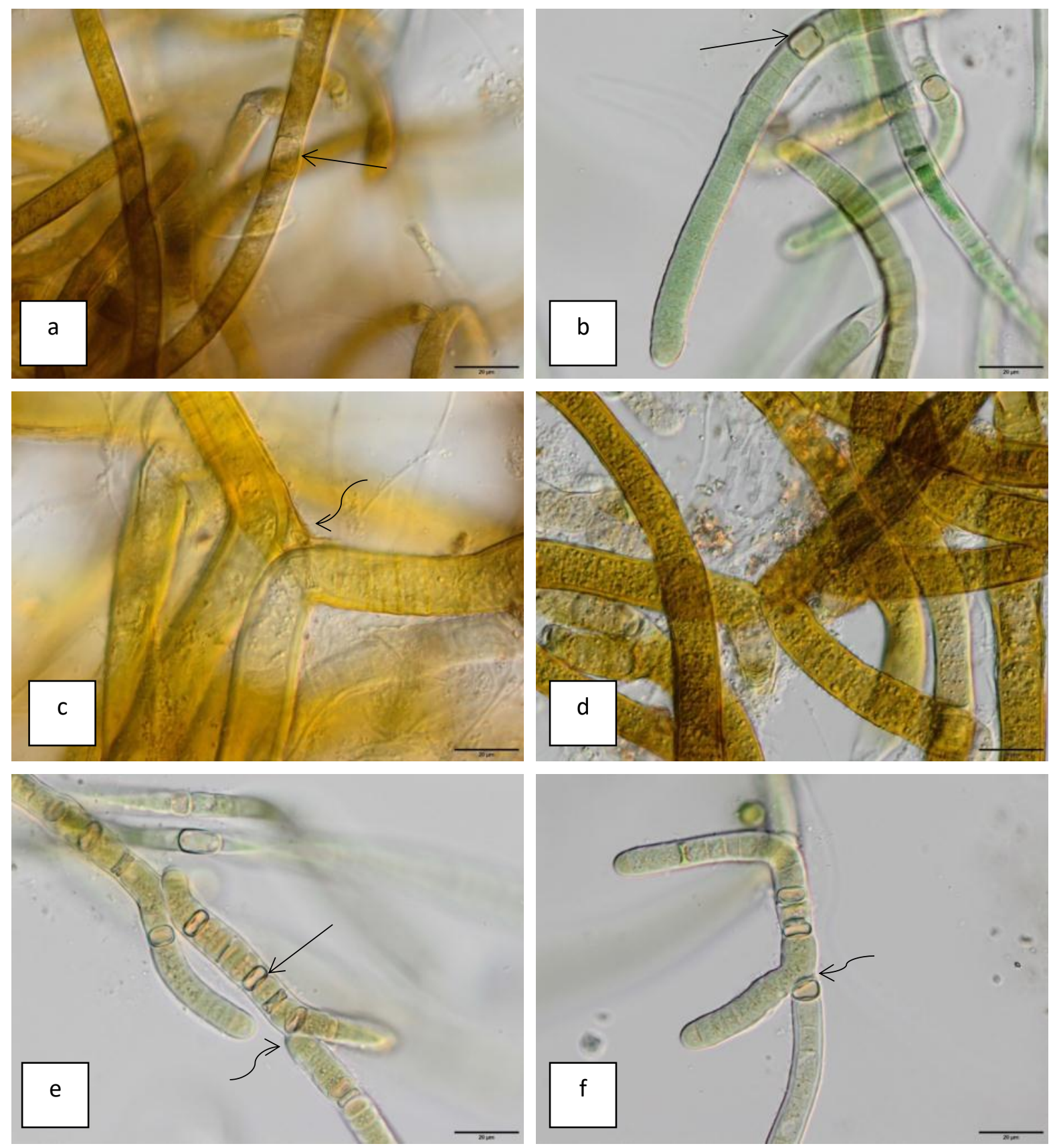

Figure S4: Scytonema species (a-f) Illustrations of three (of four) apparently different species of Scytonema that were identified; morphological attributes that differ between species included cell size and shape, size of heterocysts (straight arrows) and type of branching (curvy arrows); Scytonema sp. 2 (c-d) is heavily granulated, golden coloured and larger than the others, most common at Lake Ifould but also found elsewhere; Scytonema formed tufted or prostrate colonies on the surface and were rarely seen without UV pigmentation; note (b, e-f) are cultured specimens (scale bars $20 \mu \mathrm{m}$ ). 

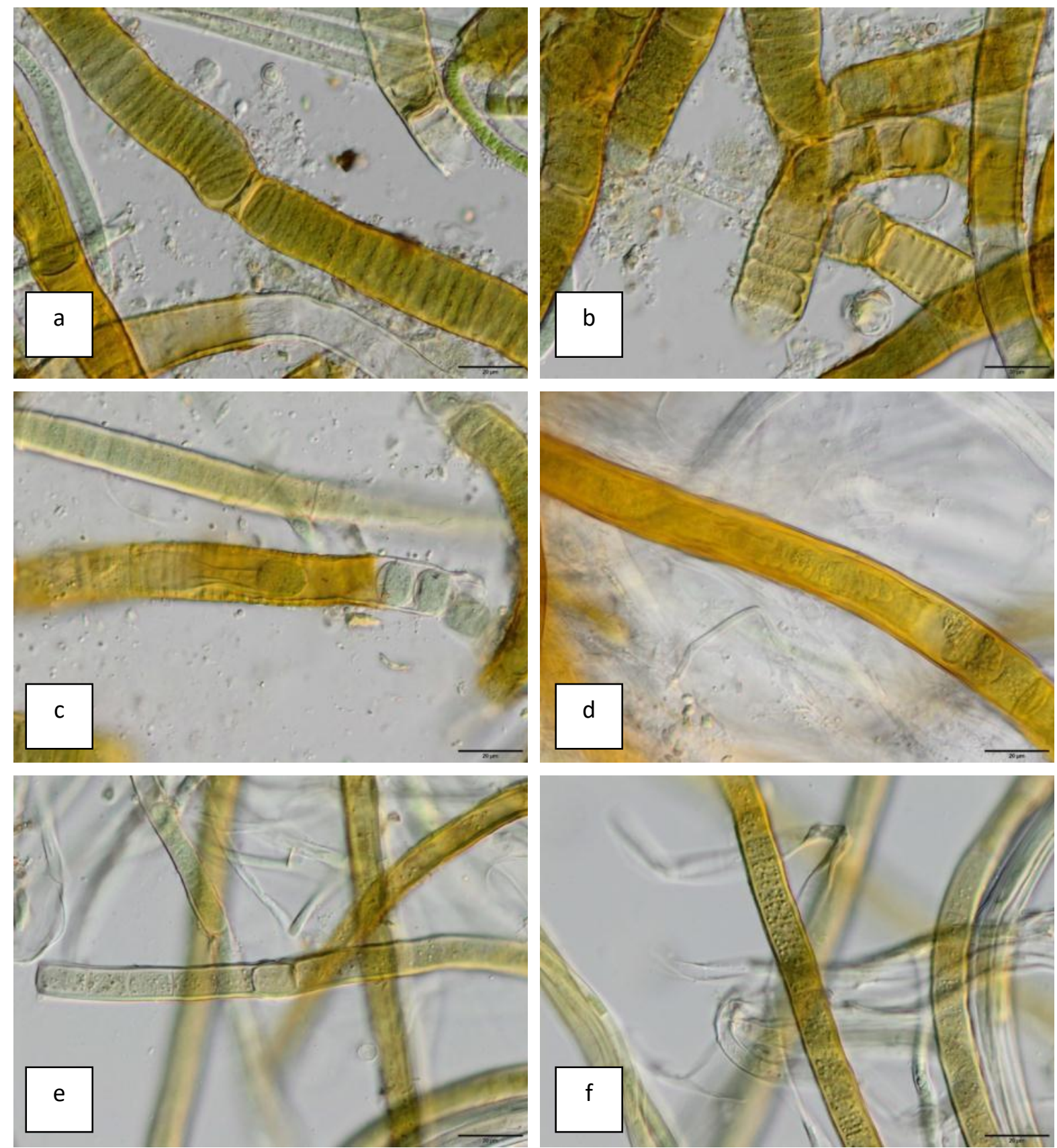

Figure S5: Brasilonema - Scytonema complex: (a-d) In these studies this species was identified as most like Brasilonema however it contained variable morphology, yet its identity was supported by molecular analysis. Brasilonema was almost twice the size of most of the Scytonema species in 4.2, contained occasional to numerous heterocytes, a range of cell shapes, false branching; (e-f) Scytonema species; (e) with longer cells than wide, similar to 4.2a and; (f) with squarish cells and heavy granulation similar to $4.2 \mathrm{~d}$; (scale bars $20 \mu \mathrm{m}$ ). 

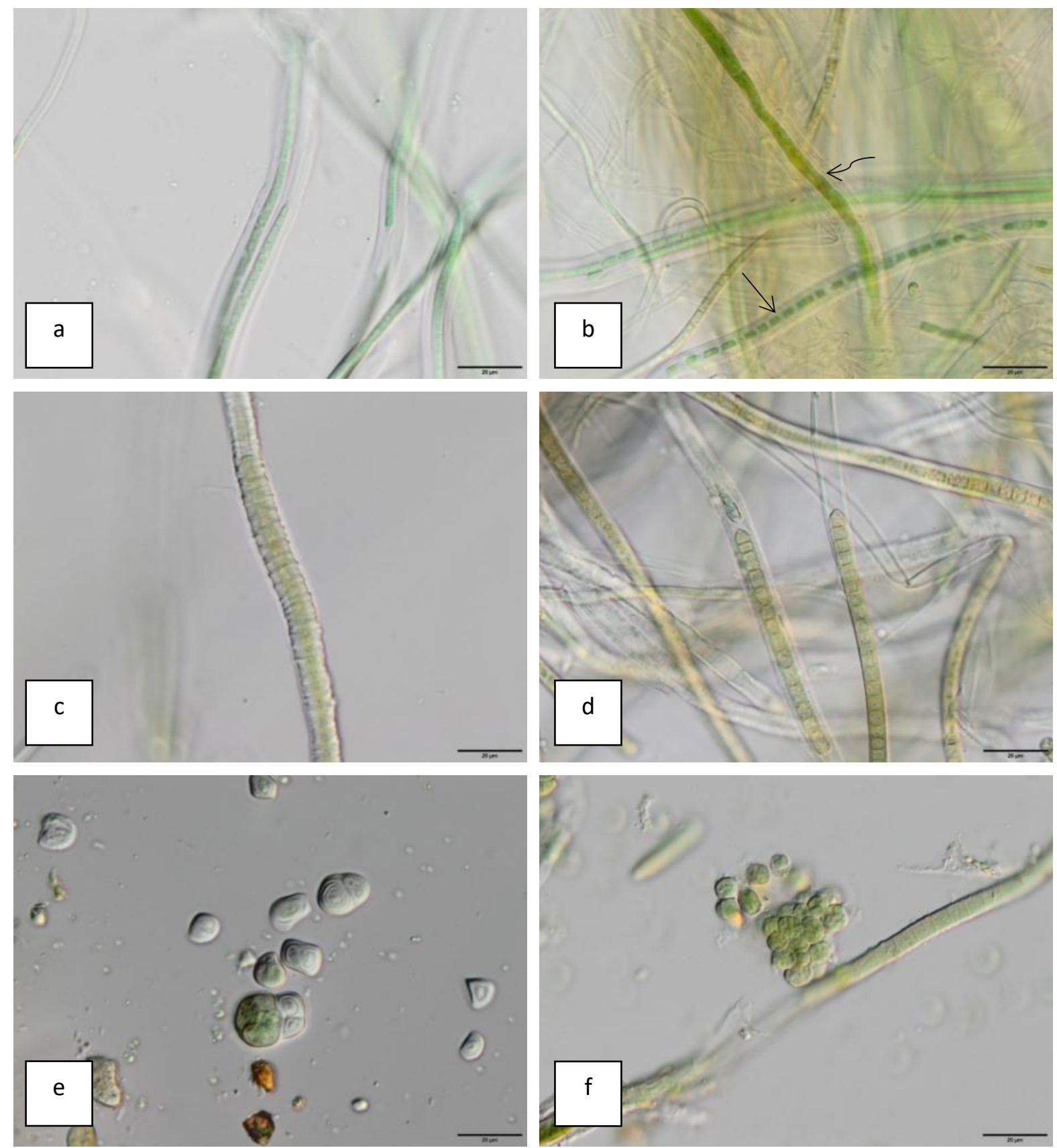

Figure S6: (a) Schizothrix species; (b) Leptolyngbya-like species (arrow) with Microcoleus (curvy arrow) and Schizothrix (background) intermingled with other cyanobacteria illustrating complex diversity within the microscale; (c-d) Porphyrosiphon species (1) that was most commonly found that when mature had a crinkled outer sheath (c); and was in very long filaments with an unusual pointed terminal cell; (e) Gloeocapsa sp. (unicellular) cyanobacterium encased in thick lamellated EPS layered envelopes; (f) unidentified unicellular Chroococcales; (scale bars $20 \mu \mathrm{m}$ ). 

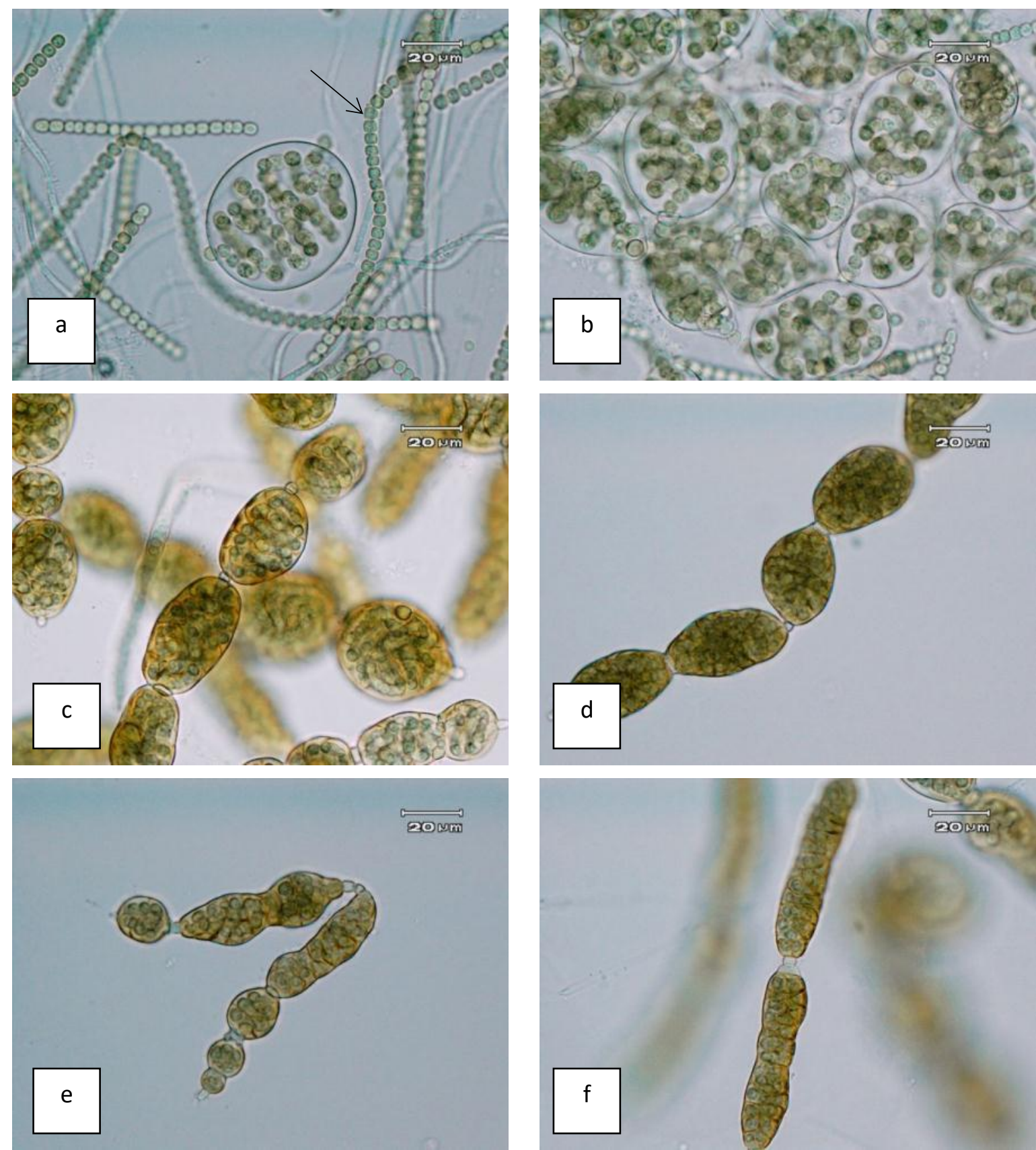

Figure S7: (a-f) Early stages and different morphs of Nostoc life cycle (cultured); (a-b) illustrating long Nostoc cf. commune chains (arrows) and sacks containing chains of Nostoc cells, about the third phase of its life cycle; (c-d) pigmentation of these cell sacks provides UV protection; (d-e) changing morphs with (e) most likely Nostoc flagelliforme (see Aboal et al., 2014); (scale bars $20 \mu \mathrm{m}$ ). 

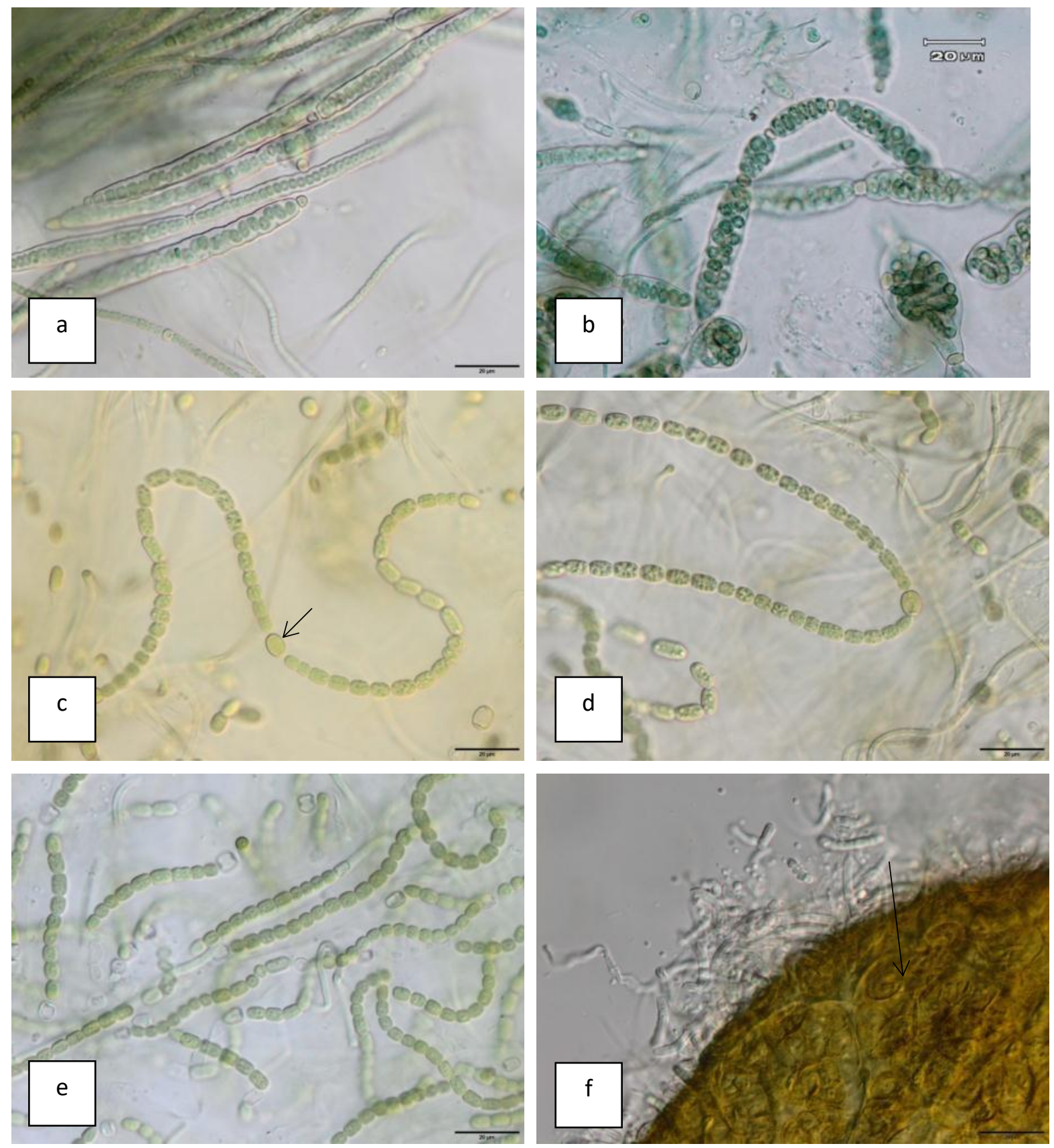

Figure S8: Nostoc species (cultured); (a-b) illustrating elongated parallel filaments of Nostoc flagelliforme possibly about the third phase of its life cycle; (c-d) long chains Nostoc cf. pruniforme with linking akinetes (arrow); (e-f) Nostoc changing morphs with (e) most likely tightly packed colonies of Nostoc commune in a thick, highly pigmented EPS envelope (arrow); (scale bars $20 \mu \mathrm{m}$ ). 

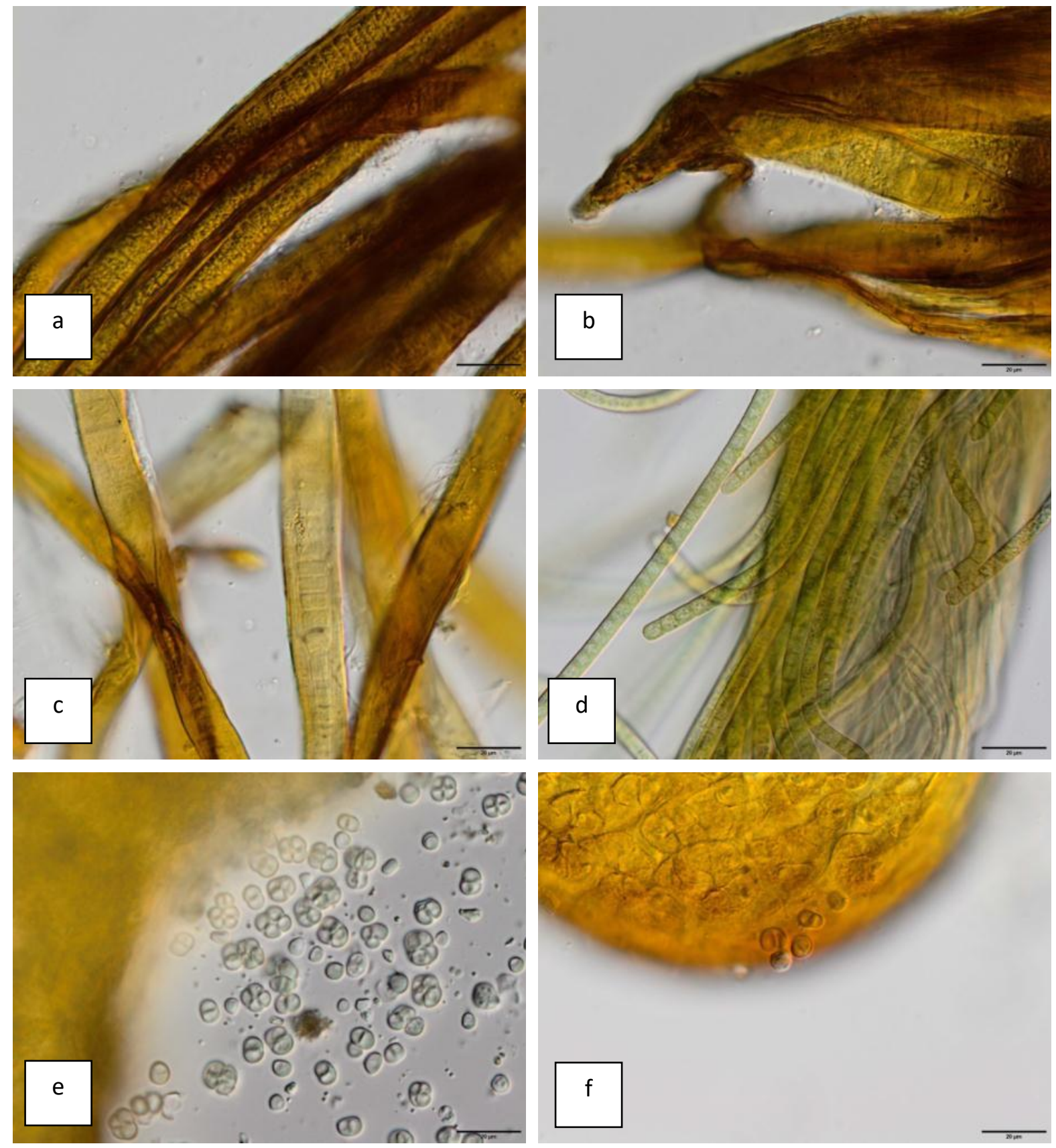

Figure S9: (a-c) Symplocastrum sp. (from Lake Ifould perimeter) with heavily granulated cells and golden to rust coloured sheaths shown forming a tuft-like peak (b) and; (c) in a partially desiccated state; (d) tightly entwined bundles of Leptolyngbya like filaments; (e-f) Chroococcus sp. from Lake Ifould perimeter in golden pigmented spherical colony (f); (scale bars $20 \mu \mathrm{m})$. 


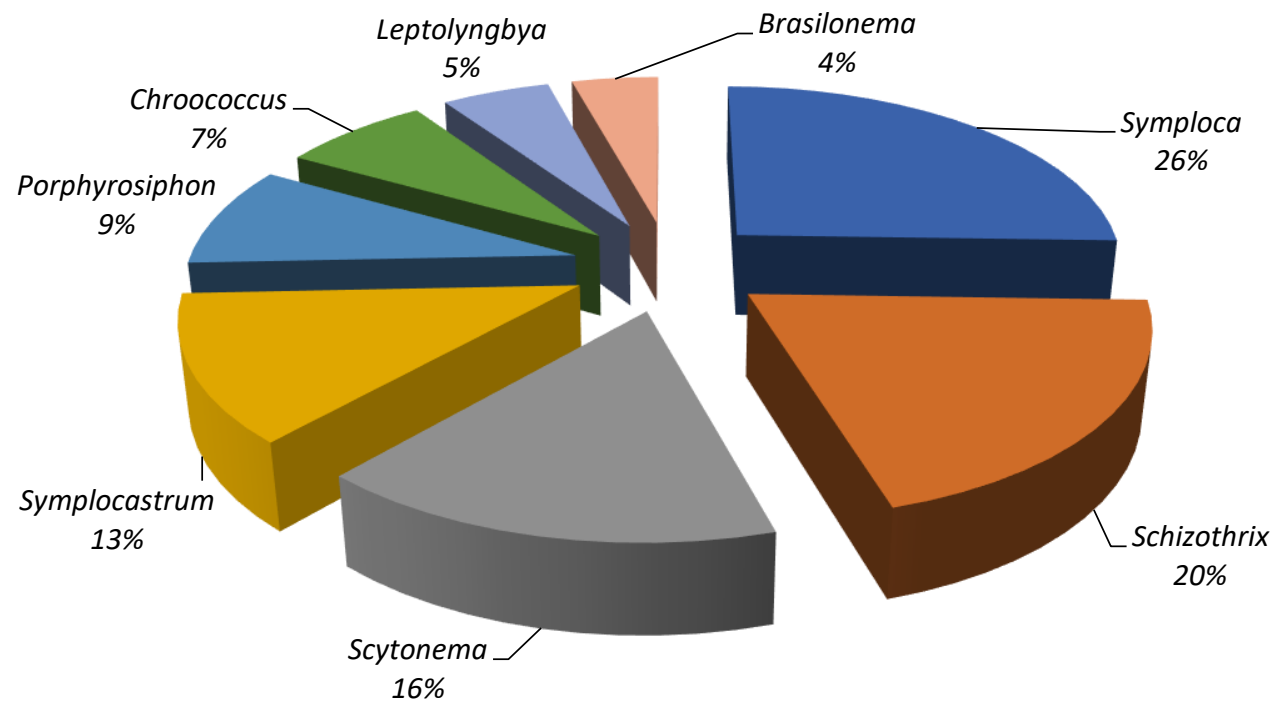

Figure S10: Cyanobacterial species richness in SMU 1 shows Symploca is dominant while sub-surface cyanobacterium Schizothrix is important for binding soil together with EPS. Symploca, Scytonema, Porphyrosiphon and Brasilonema contribute to N-fixation.

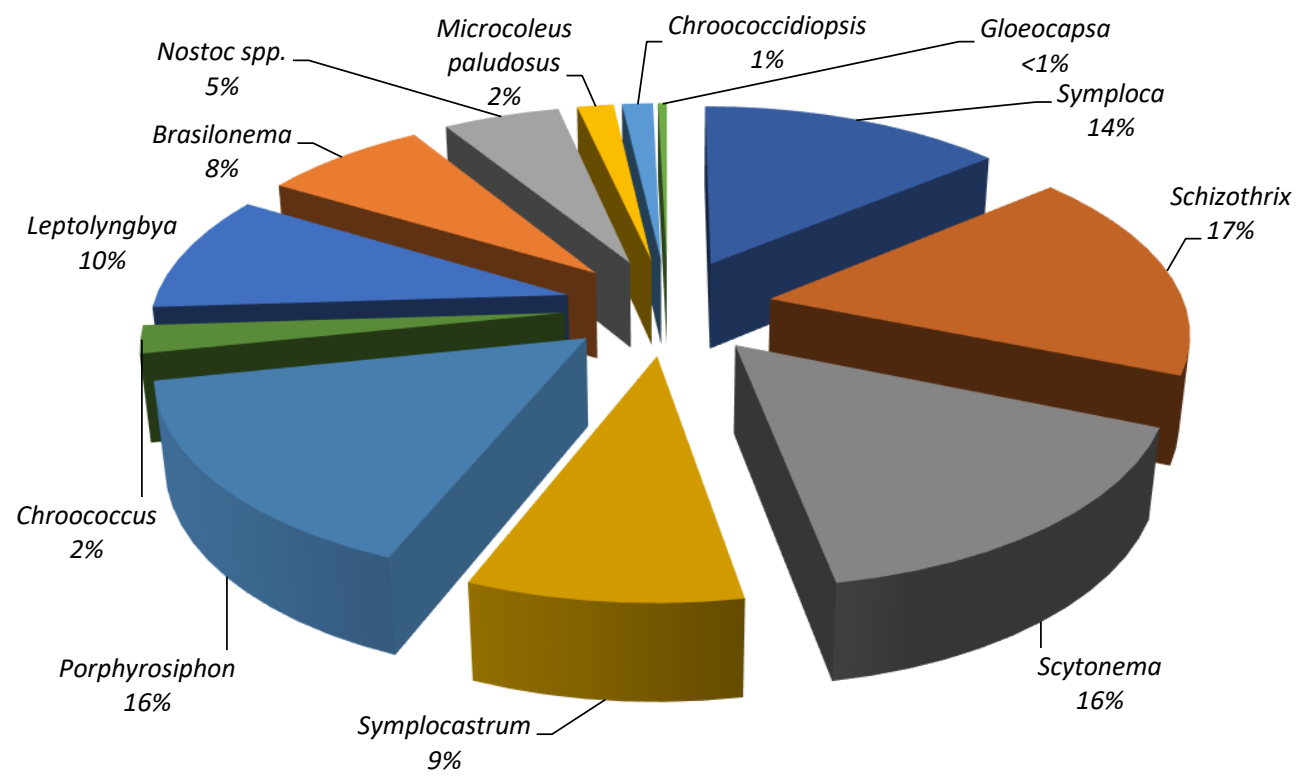

Figure S11: Cyanobacterial species richness in SMU 2 shows Schizothrix, Porphyrosiphon, Scytonema and Symploca share dominance. 


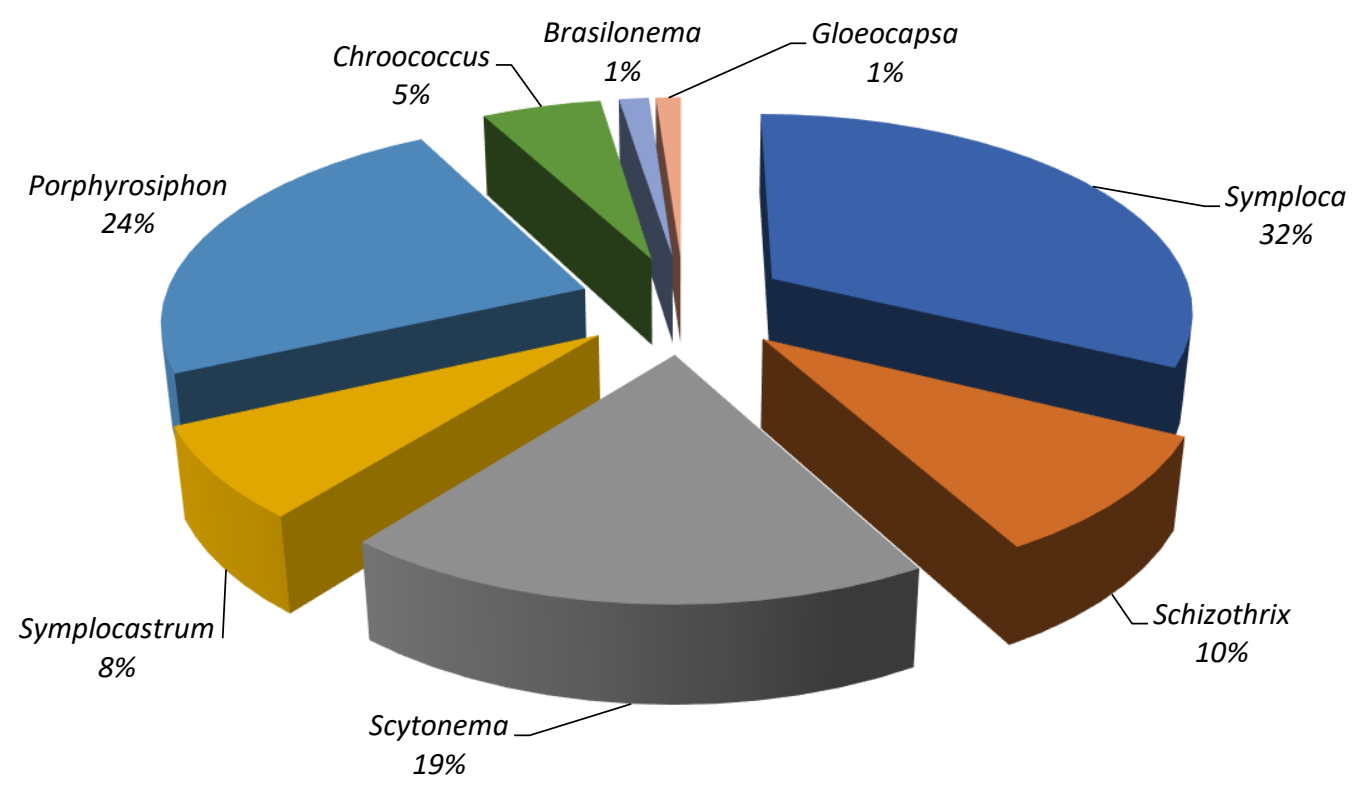

Figure S12: Cyanobacterial species richness in SMU 3 shows Symploca is clearly dominant with Porphyrosiphon and Scytonema abundant.

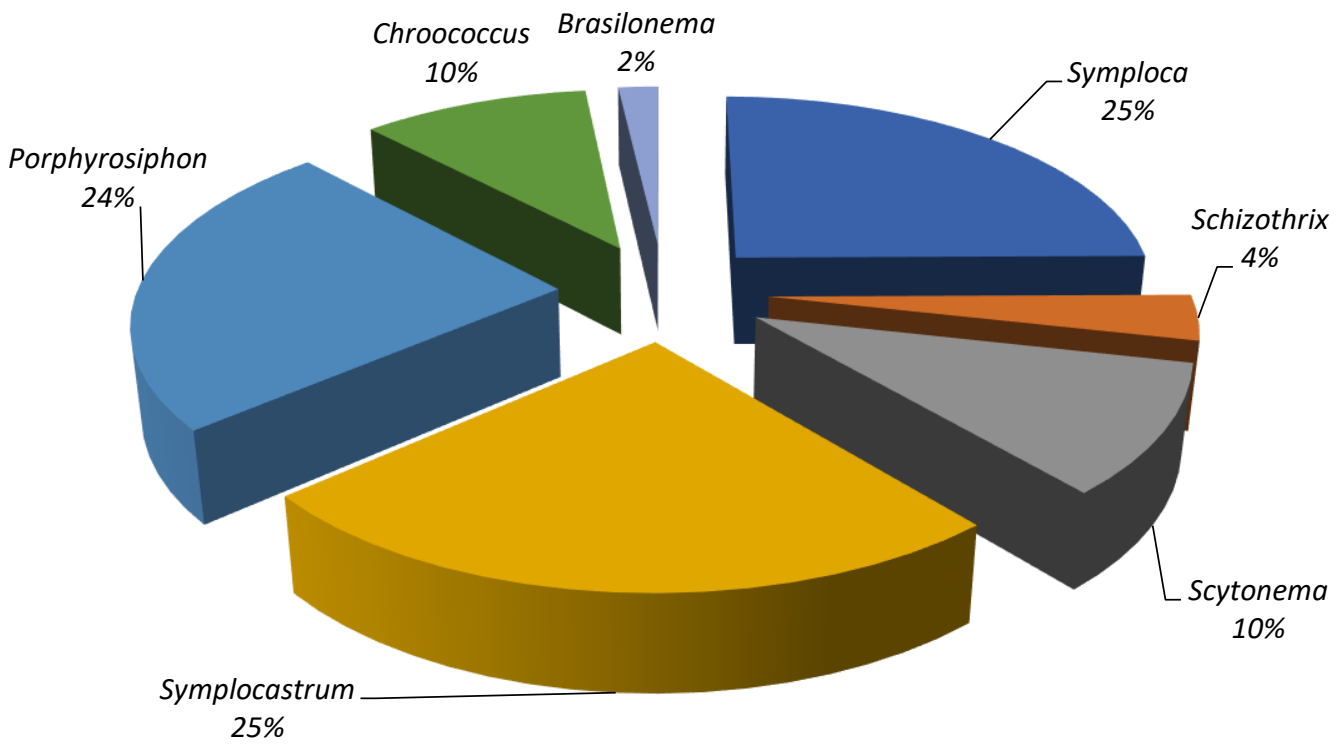

Figure S13: Cyanobacterial species richness in Site 6, the 2YO topsoil stockpile (T2) had originated from SMU 3 and mostly reflects the same dominant genera as SMU 3 (Symploca) however; Symploca and Symplocastrum are co-dominant and Porphyrosiphon abundant. N-fixing species were Symploca, Porphyrosiphon, Scytonema and Brasilonema. 